\title{
Biological Control of Pseudomonas syringae pv. syringae, the Causal Agent of Basal Kernel Blight of Barley, by Antagonistic Pantoea agglomerans
}

\author{
Andrea Braun-Kiewnick, Barry J. Jacobsen, and David C. Sands
}

Department of Plant Sciences, 205 Ag. Bioscience Building, P.O. Box 173150, Montana State University, Bozeman 59717-3150.

Current address of A. Braun-Kiewnick: Staehler Agrochemicals, Stader Elbstrasse 28, D-21683 Stade, Germany.

Accepted for publication 27 December 1999.

ABSTRACT

\begin{abstract}
Braun-Kiewnick, A., Jacobsen, B. J., and Sands, D. C. 2000. Biological control of Pseudomonas syringae pv. syringae, the causal agent of basal kernel blight of barley, by antagonistic Pantoea agglomerans. Phytopathology 90:368-375.

Strains of Pantoea agglomerans (synanamorph Erwinia herbicola) suppressed the development of basal kernel blight of barley, caused by Pseudomonas syringae pv. syringae, when applied to heads prior to the Pseudomonas syringae pv. syringae infection window at the soft dough stage of kernel development. Field experiments in 1994 and 1995 revealed 45 to $74 \%$ kernel blight disease reduction, whereas glasshouse studies resulted in 50 to $100 \%$ disease control depending on the isolate used and barley cultivar screened. The efficacy of biocontrol strains was affected by time and rate of application. Percentage of kernels infected decreased significantly when $P$. agglomerans was applied before pathogen inoculation, but not when coinoculated. A single $P$. agglomerans application 3 days prior to the pathogen inoculation was sufficient to provide control since popu-
\end{abstract}

lations of about $10^{7} \mathrm{CFU}$ per kernel were established consistently, while Pseudomonas syringae pv. syringae populations dropped 100-fold to $2.0 \times$ $10^{4} \mathrm{CFU}$ per kernel. An application to the flag leaf at EC 49 (before heading) also reduced kernel infection percentages significantly. Basal blight decreased with increasing concentrations $\left(10^{3}\right.$ to $\left.10^{7} \mathrm{CFU} / \mathrm{ml}\right)$ of $P$. agglomerans, with $10^{7} \mathrm{CFU} / \mathrm{ml}$ providing the best control. For long-term preservation and marketability, the survival of bacterial antagonists in several wettable powder formulations was tested. Over all formulations tested, the survival declined between 10 - to $>100$-fold over a period of 1.5 years $(r=-0.7 ; P=0.000)$. Although not significant, storage of most formulations at $4{ }^{\circ} \mathrm{C}$ was better for viability ( 90 to $93 \%$ survival) than was storage at $22^{\circ} \mathrm{C}$ ( 73 to $79 \%$ ). However, long-term preservation had no adverse effect on biocontrol efficacy.

Additional keywords: barley bacterial diseases, Hordeum vulgare, integrated pest management.
We previously reported about the etiology and significance of basal kernel blight of barley caused by Pseudomonas syringae pv. syringae $(29,30)$. The critical period of infection is from the late milk to soft dough stages of kernel development, and high moisture is necessary during this period for infection and disease development (28). Discolored barley has a reduced market value due to weight, yield, and quality loss $(3,5)$ and can be discounted or rejected by the malting and brewing industries when blight percentages exceed $4 \%$ in 100-g samples (30). Since no bactericides are available on small grains that might provide control of bacterial pathogens, the only mitigating measure to date is the avoidance of irrigation during the most susceptible kernel developmental stage at soft dough and the use of less-susceptible cultivars (30). Over the last 3 years, we developed an effective biocontrol system based on the application of the common phyllosphere colonist Pantoea agglomerans prior to the Pseudomonas syringae pv. syringae infection window $(10,12,13)$. P. agglomerans, synanamorph Erwinia herbicola $(15,17)$, has been used as a biological control agent (BCA) against several fungal and bacterial diseases. Seed treatment with $P$. agglomerans protected wheat from infection by Fusarium culmorum (22), F. nivale, and Pythium ultimum $(1,32)$. Seed bacterization with an $P$. agglomerans isolate also inhibited Rhizoctonia solani, thus providing sheath blight protection (35). A strain of $P$. agglomerans isolated from sclerotia of Verticillium dahliae was found to inhibit this pathogen in vitro (8). In the phyllosphere, P. agglomerans was reported to control Puccinia recondita f. sp. tritici on wheat (22), Alternaria solani on tomato (39),

Corresponding author: B. J. Jacobsen; E-mail address: uplbj@montana.edu

Publication no. P-2000-0221-02R

(C) 2000 The American Phytopathological Society and Sclerotinia sclerotiorum on dry edible beans (41). Plant growthpromoting effects of $P$. agglomerans strains from the winter wheat phyllosphere were noted by Ruppel et al. (36) and Scholz-Seidel and Ruppel (37). The authors detected wheat and barley yield increases of up to $500 \mathrm{~kg} / \mathrm{ha}$ in field experiments with prebacterized seeds. Furthermore, Amellal et al. (2) described a positive effect of $P$. agglomerans in the regulation of the water content of the wheat rhizosphere by improving soil aggregation. Control of bacterial diseases by $P$. agglomerans has involved antagonism against ice nucleation active (INA-plus) bacteria $(26,27)$ and several other bacterial pathogens. These include protection of cotton seeds from Xanthomonas campestris pv. malvacearum (34); rice seedlings from $X$. oryzae (18); mungbeans from $X$. campestris pv. vingnaeradiatae (9); and the control of the fire blight pathogen E. amylovora on apples $(6,7,21,38)$, pear $(20,38)$, and hawthorn (40). The objectives of the current study were to develop an effective and practical biocontrol system using $P$. agglomerans to suppress Pseudomonas syringae pv. syringae and the development of basal kernel blight. In addition to field and glasshouse studies, we present data on the time of BCA application and the concentration needed for successful disease prevention. Furthermore, we investigated the population dynamics of an antibiotic-resistant pathogen and antagonist population and evaluated the effectiveness of several formulations for long-term preservation of these bacterial antagonists.

\section{MATERIALS AND METHODS}

Bacterial cultures and inoculum preparation. $P$. agglomerans strains were isolated from asymptomatic barley kernels in fields that had endemic basal kernel blight in Fairfield, MT, in 1990, 1993, and 1994. Pseudomonas syringae pv. syringae strains (Pss) were isolated from barley kernels showing symptoms of basal blight in 
1993 to 1995 . Isolates were identified according to standard tests (16) and based on the BIOLOG GN (Biolog, Inc., Hayward, CA) and MIDI (Microbial ID Inc., Newark, DE) identification systems. They were stored at $-70^{\circ} \mathrm{C}$ in nutrient broth containing $15 \%$ glycerol. To produce cells for barley head inoculation, bacteria were retrieved from storage, streaked onto King's medium B agar (Pseudomonas syringae pv. syringae) (23) or tryptic soy agar (TSA) (Difco Laboratories, Detroit) (P. agglomerans), and incubated at $28^{\circ} \mathrm{C}$ for 48 or $24 \mathrm{~h}$, respectively. Cells were suspended in $10 \mathrm{ml}$ of phosphate-buffered saline (PBS) buffer $(0.85 \% \mathrm{NaCl}, 0.03 \mathrm{M} \mathrm{NaOH}$, and $0.05 \mathrm{M} \mathrm{KH}_{2} \mathrm{PO}_{4}, \mathrm{pH} 7.0$ ) and the density of the suspension adjusted to $10^{8} \mathrm{CFU} / \mathrm{ml}$. The suspension was diluted $1: 10$ in $90 \mathrm{ml}$ of sterile water containing $0.025 \%$ Tween 20 (polyoxyethylenesorbitan monolaurate) as surfactant to a final concentration of $10^{7} \mathrm{CFU} / \mathrm{ml}$. In the glasshouse, Pseudomonas syringae pv. syringae strains were inoculated on barley heads at the soft dough stage (EC 85). In field experiments, natural infection by Pseudomonas syringae pv. syringae was enhanced by brief periods of daily overhead sprinkler irrigation for 5 to 10 days during the window of infection (30).

Application of $\boldsymbol{P}$. agglomerans in field experiments. In 1994, four $P$. agglomerans strains (Eh 236, Eh 239, Eh 454, and Eh 460) were sprayed on barley cvs. B 2601 and B 1202 at Fairfield, MT, prior to the expected infection window for Pseudomonas syringae pv. syringae attack at the late milk stage (EC 77; 10 July). Natural infection was favored by providing overhead sprinkler irrigation for $4 \mathrm{~h}$ in the morning and $4 \mathrm{~h}$ in the evening for 5 days during the dough stages (EC 83 to EC 85 ) from 14 to 18 July, delivering an average of $15 \mathrm{~mm}$ of water per $4 \mathrm{~h}$ of irrigation (30). Traces of precipitation $(0.6 \mathrm{~mm})$ fell from 14 to 23 July in addition to the $150 \mathrm{~mm}$ provided by irrigation. Fifty milliliters of biocontrol bacterial suspensions $\left(1 \times 10^{9} \mathrm{CFU} / \mathrm{ml}\right)$ were sprayed per $1.5-\mathrm{m}$ row $\left(0.4\right.$ liter $\left./ 3.5 \mathrm{~m}^{2}\right)$ on barley heads until run-off using a compressed air sprayer (KGRO all purpose plant sprayer; K-mart Corp., Troy, MI). Assuming an average of 100 plants with 153 spikes per row and about 30 kernels per spike, the application rate was $1.0 \times$ $10^{7} \mathrm{CFU}$ per kernel. A water/Tween 20 check; heat-killed Eh 236, Eh 239, Eh 454, and Eh 460; and the fungicide Tilt (propiconazole; Novartis Crop Protection, Greensboro, NC) applied at 0.3 liter/ha on 17 June were used as controls. The effect of Tilt on the disease was tested due to the observation of increased blight levels by farmers in their barley fields in the Fairfield area. The experiment was conducted as a two-factorial split plot design with cultivars as main plots (two levels) and treatments as subplots (10 levels) with four blocks. Each treatment was applied to a $1.5-\mathrm{m}$ row within a plot consisting of six rows, $30 \mathrm{~cm}$ apart. The two border rows remained untreated and $60-\mathrm{cm}$ alleys separated plots. Fifteen barley heads randomly selected at the soft dough stage (EC 85) represented one sample per replication and were picked at harvest and evaluated for basal kernel blight infection. Percentage of infection was calculated after harvest (2 August) according to the following formula: \% kernel blight $=(a / b) \times 100$, in which $a=$ number of blighted kernels per sample, and $b=$ total number of kernels per sample.

All treatments were compared with nontreated water/Tween 20 controls of each cultivar to derive blight reduction data. In 1995, the same four $P$. agglomerans strains used in 1994 were sprayed on the four barley cvs. B 2601, B 2912, B 5133, and B 1202 prior to the infection window at the early milk stage (EC 73). In 1995 field experiments, $200 \mathrm{ml}$ of bacterial suspensions at a concentration of $4.0 \times 10^{8} \mathrm{CFU} / \mathrm{ml}$ were sprayed until run-off per $1.5-\mathrm{m}$ row (3.0 liters $/ 5 \mathrm{~m}^{2}$ ) on barley heads on 13 July. Assuming an average of 100 plants with 153 spikes per row and about 30 kernels per spike, the application rate was $1.0 \times 10^{7} \mathrm{CFU}$ per kernel. Control treatments included the water/Tween 20 check and autoclaved bacterial antagonists. Additional treatments consisted of a $50 \mathrm{mM} \mathrm{L-}$ tartaric acid ( $\mathrm{pH} 3.5)$ treatment, biocontrol strain combinations, and the Tilt application on 20 June. The tartaric acid treatment was included in the 1995 field study as a means of bacterial disease con- trol because of its consistent reduction of the fire blight disease in Montana apple orchards (D. C. Sands, unpublished data). Sprinkler irrigation provided $300 \mathrm{~mm}$ of precipitation from the early milk to hard dough stages (15 to 25 July). Additionally, $16 \mathrm{~mm}$ of rain fell during the irrigation period. Disease evaluation was completed after harvest (22 August) in the same way as in 1994. The experiment was conducted as a two-factorial split plot design with cultivars as main plots (four levels) and treatments as subplots (16 levels) with four blocks.

P. agglomerans application in glasshouse experiments. In 1994, two $P$. agglomerans strains (Eh 454 and Eh 239) were sprayed on cvs. B 1202 and B 2601, respectively, at the soft dough stage 3 days prior to inoculation with Pseudomonas syringae pv. syringae strain Pss 552. A water/Tween 20 application, the positive pathogen control (Pss 552), and the heat-killed strain Eh 239 were included as controls. One pot (19 $\mathrm{cm}$ in diameter) with three barley spikes per replication $(n=5)$ was inoculated and BCAs sprayed on heads until run-off (approximately $5 \mathrm{ml}$ per spike) using a hand air brush sprayer (model Paaschi D500 1/10 H.P.; Paaschi Inc., New York). Plants were incubated in a mist chamber (95\% relative humidity) for $72 \mathrm{~h}$ after BCA application. Thereafter, the pathogen Pss 552 was inoculated and plants incubated again for $72 \mathrm{~h}$ before being transferred to the glasshouse bench. The glasshouse was maintained at $22 / 18 \pm 2{ }^{\circ} \mathrm{C}$ (day/night) with a 12 -h photoperiod. Basal kernel blight percentages were calculated after harvest by the formula described above and blight reduction data obtained by comparing treatments with the positive control. Each experiment (cultivar) was conducted as a one-factorial completely randomized design (CRD). The same experiment was performed in 1995 using strains Eh 236 and Eh 460 instead of strains Eh 454 and Eh 239 to see differences in the efficacy of different antagonistic bacteria. To investigate the performance of biocontrol strains against several pathogenic Pseudomonas syringae pv. syringae strains, a glasshouse experiment was conducted in 1997 as a one-factorial CRD with eight treatments and four replications. The biocontrol strains Eh 460, Eh 237, and Eh 234 were sprayed on cv. B 2601 heads 3 days prior to pathogen Pss 552 or Pss 793 inoculation at the soft dough stage. Controls included the Pss 552 and Pss 793 positive checks. Plant incubation and disease evaluation was carried out as described above.

Time and rate of BCA application. In most experiments, bacterial antagonists were applied 3 days prior to the pathogen inoculation or enhanced natural infection. To determine whether time of biocontrol application was critical, a glasshouse experiment was conducted in 1996 as a one-factorial CRD with four treatments and five replications. Treatments were a chloramphenicol-resistant P. agglomerans strain Eh $460 \mathrm{chl}^{\mathrm{R}}$, which was applied to barley heads (cv. B 2601) at the soft dough stage 3 days prior to a rifampicinresistant Pseudomonas syringae pv. syringae strain Pss 552 rif $^{\mathrm{R}}$ inoculation $(=3 \mathrm{~d}$, conventional application); the application of strain Eh $460 \mathrm{chl}^{\mathrm{R}}$ immediately before inoculation of Pss $552 \mathrm{rif}^{\mathrm{R}}$ (=0d, coinoculation); and control applications of Pss $552 \mathrm{rif}^{\mathrm{R}}$ and water/Tween 20. Eh $460 \mathrm{chl}^{\mathrm{R}}$ was applied at a concentration of $7.9 \times$ $10^{7} \mathrm{CFU} / \mathrm{ml}$ and Pss 552 rif $^{\mathrm{R}}$ at $6.3 \times 10^{7} \mathrm{CFU} / \mathrm{ml}$. The spontaneous antibiotic-resistant mutations had no effect on pathogenicity, survival, or biocontrol activity of either strain Pss 552 rif $^{\mathrm{R}}$ or strain Eh $460 \mathrm{chl}^{\mathrm{R}}$ as determined by in vitro and in vivo tests (data not shown). Plant inoculation, incubation, and disease evaluation after harvest were done as described above. The experiment also included a population dynamics study to investigate the development of the pathogen population after introduction of biocontrol bacteria in the barley phyllosphere under controlled conditions. The experiment used a CRD with four treatments, eight reisolation dates, and four replications (four treatments $\times$ eight dates $\times$ four replications $=128$ heads $=44$ pots with three plants per pot). Treatments consisted of Eh $460 \mathrm{chl}^{\mathrm{R}}$ application 3 days prior to Pss 552 rif $^{\mathrm{R}}$ inoculation at the soft dough stage (Eh $\left.460 \mathrm{chl}^{\mathrm{R}} 3 \mathrm{~d}\right)$; coinoculation of Eh $460 \mathrm{chl}^{\mathrm{R}}$ and Pss $552 \mathrm{rif}^{\mathrm{R}}$ (Eh $460 \mathrm{chl}^{\mathrm{R}}$ 0d); inocula- 
tion of Pss 552 rif $^{\mathrm{R}}$ alone (Pss 552); and inoculation of Eh 460 $\mathrm{chl}^{\mathrm{R}}$ alone (Eh $460 \mathrm{chl}^{\mathrm{R}}$ ). Thirty-five kernels from each of four barley heads (replications) were randomly collected per treatment and shaken $(150 \mathrm{rpm})$ in $50 \mathrm{ml}$ of PBS buffer containing $155-\mathrm{mm}$ glass beads for $30 \mathrm{~min}$ at $22^{\circ} \mathrm{C}$. The suspensions were serially diluted and plated on semiselective King's medium B plus boric acid and cephalexin (31) amended with $100 \mu \mathrm{g}$ of rifampicin per ml for Pss 552 rif $^{\mathrm{R}}$ reisolation and on TSA amended with $60 \mu \mathrm{g}$ of chloramphenicol per $\mathrm{ml}$ for Eh $239 \mathrm{chl}^{\mathrm{R}}$ reisolation. Epiphytic bacterial population sizes were expressed as log CFU per kernel. The mean log-transformed population size of each strain was estimated from four heads ( 35 kernels) and six plate replicates per treatment.

The question of whether the BCA could be introduced earlier than the soft dough stage was examined in a separate glasshouse experiment in 1997 by applying P. agglomerans strain Eh 239 at EC 49, the last stage of booting before seedhead emergence. Pathogen Pseudomonas syringae pv. syringae strain Pss 552 was inoculated at the soft dough stage (EC 85). Other treatments included the conventional Eh 239 application at EC 853 days prior to inoculation of the pathogen, the water control, and the Pss 552 positive control. The experiment was conducted as a CRD with four treatments and five replications. Plant inoculation, incubation, and disease evaluation were performed in the same way as described above.

To estimate the rate $(\mathrm{CFU} / \mathrm{ml})$ of BCAs needed for disease control, a glasshouse experiment was conducted in 1996. P. agglomerans strain Eh 460 was sprayed on cv. B 2601 barley heads at EC 85 at concentrations of $10^{3}, 10^{5}$, and $10^{7} \mathrm{CFU} / \mathrm{ml} 3$ days prior to Pss 552 inoculation. The water/Tween 20 and the Pss 552 treatment without $P$. agglomerans antagonists served as controls. The experiment was performed as a CRD, with five treatments and six replications. Plant inoculation, incubation, and disease evaluation were done as previously described.

Formulation of $\boldsymbol{P}$. agglomerans. Formulations of BCAs were prepared using the oil/starch/sugar encapsulation method developed by Quimby et al. (33). Briefly, this involved growing the BCAs on TSA plates overnight at $28^{\circ} \mathrm{C}$. Plates were overlaid with $10 \mathrm{ml}$ of $1 \mathrm{M}$ sucrose solution and bacteria scraped off the plates into 100-ml sterile beakers using a sterile cotton swab. Five grams of the water-absorbent starch Water-lock (Grain Processing Corporation, Muscatine, IA) and $5 \mathrm{ml}$ of unrefined corn oil (Spectrum Naturals Inc., Petaluma, CA) were added to each beaker. These

TABLE 1. Percentage of basal blight disease incidence over all cultivars and percentage of kernel blight reduction on barley cvs. B 2601 and B 1202 obtained in a field experiment at Fairfield, MT, in 1994

\begin{tabular}{lccc}
\hline & $\begin{array}{c}\text { Disease incidence } \\
\text { all cultivars (\%) }\end{array}$ & B 1202 & B 2601 \\
\cline { 3 - 4 } Treatment $^{\mathrm{w}}$ & $2.3 \mathrm{a}^{\mathrm{x}}$ & $\ldots$ & $\ldots$ \\
$\mathrm{H}_{2} \mathrm{O}$ & $1.1 \mathrm{c}$ & 33 & $59^{* \mathrm{y}}$ \\
Eh 236 & $0.9 \mathrm{c}$ & 50 & $68^{*}$ \\
Eh 239 & $1.4 \mathrm{bc}$ & 30 & $45^{*}$ \\
Eh 454 & $0.9 \mathrm{c}$ & 58 & $65^{*}$ \\
Eh 460 & $2.2 \mathrm{a}$ & 0 & 26 \\
Eh 236 D & $2.5 \mathrm{a}$ & 0 & 17 \\
Eh 239 D & 0 & 27 \\
Eh 454 D & $2.7 \mathrm{a}$ & 0 & 27 \\
Eh 460 D & $2.0 \mathrm{ab}$ & 0 & 25 \\
Tilt & $2.3 \mathrm{a}$ & $\ldots$ & $\ldots$ \\
LSD $(0.05)$ & 0.82 & & $\ldots$
\end{tabular}

w The water/Tween 20 check; biocontrol Pantoea agglomerans strains Eh 236, Eh 239, Eh 454, and Eh 460; heat-killed bacteria (D); or Tilt were applied to plant heads at the late milk stage prior to the Pseudomonas syringae pv. syringae infection window.

$x$ Values are means of four replicates and two cultivars, and values followed by the same letter are not significantly different at $P \leq 0.05$ according to Fisher's protected least significant difference (LSD) test.

y* = Significant reduction values of treatments compared with those of nontreated controls within a cultivar at $P \leq 0.05$ using single-degree-of-freedom contrasts.

${ }^{\mathrm{z}} \mathrm{D}=$ Heat-killed bacteria. primary components were blended into a doughlike mass in a mixer (Sigma Chemical Co., St. Louis). A total of $17.5 \mathrm{~g}$ of the silicabased granulating agent Hi-Sil (Cabot Corp., Tuscola, IL) was added and blending continued until the dough crumbed, thereby producing a granular product. The wettable powder granules were spread in foil pans and air-dried in a laminar flow cabinet for $48 \mathrm{~h}$ at room temperature. The dried formulation was then sieved in the size range of 250 to $710 \mu \mathrm{m}$ and viable bacterial colony counts recorded over a period of 1.5 years for $P$. agglomerans strains Eh 239 and EhL13 stored at 22 and $4{ }^{\circ} \mathrm{C}$, respectively. For lyophilization, strains Eh 239 and Eh 460 were grown in $200 \mathrm{ml}$ of $2 \%$ potato dextrose broth (Difco Laboratories) for $20 \mathrm{~h}$, centrifuged at $6,000 \times g$ (DuPont Sorvall RC 5-B; DuPont Instruments Inc., Newtown, CT) for $15 \mathrm{~min}$, and the cell pellet resuspended in $10 \mathrm{ml}$ of PBS buffer. Ten percent dry milk powder (pasteurized nonfat dry milk, fortified with vitamins A and D, but no preservatives; Carnation Company, Los Angeles, CA) was added as a food base and the suspension vortexed. Samples were freeze-dried (freeze dry system/ Lyphlock 4.5; Labconco, Kansas City, MO) for 24 to $48 \mathrm{~h}$ following freezing in liquid nitrogen for $10 \mathrm{~min}$. Strains were kept at $4^{\circ} \mathrm{C}$ and viable colony counts recorded over time. For dry milk formulation of strain EhL13, the oil/starch/sugar encapsulation method was slightly modified by replacing starch with $10 \mathrm{~g}$ of dry milk powder. The powder was stored at room temperature over a storage period of 1.5 years. Viable colony counts were performed by adding $0.1 \mathrm{~g}$ of powdered granules to $9.9 \mathrm{ml}$ of PBS buffer and vortexing for $1 \mathrm{~min}$. Serial dilutions were prepared from this stock solution to $10^{-7}$ and spiral plated on TSA plates. Bacterial numbers were calculated as $\log \mathrm{CFU} / \mathrm{g}$ of powdered formulation and isolations were done 1 day, 2 weeks, 4 weeks, 3 months, 6 months, 1 year, and 1.5 years after formulation.

Statistical analyses. All statistical analyses were performed as appropriate to the experimental design using the MSU STAT statistical analysis package (Microcomputer version 5.2; Montana

TABLE 2. Percentage of basal kernel blight disease incidence over all cultivars and percentage of blight reduction on barley cvs. B 2601, B 2912, B 1202 , and B 5133 obtained in a field experiment at Fairfield, MT, in 1995

\begin{tabular}{|c|c|c|c|c|c|}
\hline \multirow[b]{2}{*}{ Treatment $^{\mathrm{w}}$} & \multirow{2}{*}{$\begin{array}{l}\text { Disease incidence } \\
\text { all cultivars }(\%)\end{array}$} & \multicolumn{4}{|c|}{$\%$ Blight reduction } \\
\hline & & B 2601 & B 2912 & B 1202 & В 5133 \\
\hline $\mathrm{H}_{2} \mathrm{O}$ & $7.7 \mathrm{a}^{\mathrm{x}}$ & & & & \\
\hline Eh 236 & $3.4 \mathrm{~g}-\mathrm{i}$ & $48.9 * y$ & $66.5^{*}$ & $52.86^{*}$ & 51.16 \\
\hline Eh 239 & $2.7 \mathrm{hi}$ & $60.3^{*}$ & $73.8^{*}$ & $67.14^{*}$ & 48.83 \\
\hline Eh 454 & $2.6 \mathrm{i}$ & $68.9 *$ & $64.2 *$ & $68.57 *$ & $61.39 *$ \\
\hline Eh 460 & $3.5 \mathrm{~g}-\mathrm{i}$ & $60.3^{*}$ & $60.0^{*}$ & $64.3^{*}$ & 36.7 \\
\hline Eh $236 D^{z}$ & $6.5 \mathrm{a}-\mathrm{d}$ & 23.9 & 0.0 & 28.6 & 12.1 \\
\hline Eh $239 D^{z}$ & $7.2 \mathrm{ab}$ & 0.0 & 0.0 & 11.4 & 20.5 \\
\hline Eh $454 D^{z}$ & $5.9 \mathrm{~b}-\mathrm{d}$ & 0.0 & 45.6 & $52.9^{*}$ & 18.1 \\
\hline Eh $460 D^{z}$ & $6.6 \mathrm{a}-\mathrm{c}$ & 0.0 & 13.8 & $38.6^{*}$ & 26.5 \\
\hline Eh $239+454$ & $5.2 \mathrm{c}-\mathrm{f}$ & $48.4^{*}$ & 40.7 & $64.3^{*}$ & 33.5 \\
\hline Eh $460+236$ & $5.1 \mathrm{~d}-\mathrm{f}$ & $44.2 *$ & 46.8 & $34.3^{*}$ & $58.1 *$ \\
\hline Eh $239+460$ & $4.1 \mathrm{f}-\mathrm{h}$ & $42.1 *$ & 26.9 & $42.9 *$ & 10.7 \\
\hline Eh $236+239$ & $4.2 \mathrm{fg}$ & $42.1 *$ & 25.9 & $62.9 *$ & 20.0 \\
\hline All Eh & $4.4 \mathrm{e}-\mathrm{g}$ & $45.5^{*}$ & $52.3^{*}$ & $45.7 *$ & 16.3 \\
\hline Tartaric acid & $6.5 \mathrm{a}-\mathrm{d}$ & 26.0 & 20.3 & $35.7 *$ & 20.5 \\
\hline Tilt & $5.7 \mathrm{c}-\mathrm{e}$ & $40.3^{*}$ & 0.0 & 25.7 & 43.3 \\
\hline LSD (0.05) & 1.4 & $\ldots$ & $\ldots$ & $\ldots$ & $\ldots$ \\
\hline
\end{tabular}

${ }^{\text {w }}$ The water/Tween 20 check; biocontrol Pantoea agglomerans strains Eh 236, Eh 239, Eh 454, and Eh 460; heat-killed bacteria (D); biocontrol strain combinations; a $50 \mathrm{mM}$ L-tartaric acid treatment; and Tilt were applied to barley heads at the early milk stage prior to the Pseudomonas syringae pv. syringae infection window.

$x$ Values are means of four replicates and four cultivars; data were log-transformed prior to analysis and values followed by the same letter are not significantly different at $P \leq 0.05$ according to Fisher's protected least significant difference (LSD) test.

$\mathrm{y} *=$ Significant reduction values of treatments compared with those of the nontreated controls within a cultivar at $P \leq 0.05$ using single-degree-of-freedom contrasts.

${ }^{\mathrm{z}} \mathrm{D}=$ Heat-killed bacteria. 
State University, Bozeman). Data were analyzed by analysis of variance (ANOVA), and the sources and amount of variation were compared using an $F$-ratio test. When variances were not homogeneous in the Bartlett's test for homogeneity, a probability of significance was calculated using the ANOVA $F$-ratio test performed on the linearized data after transformation. To compare differences between two treatment means, Student's $t$ tests were performed. To compare multiple treatment means, least significant differences were calculated by Fisher's least significant difference test at $\alpha=5 \%$ unless stated otherwise. Means followed by different letters demonstrated a statistical significant difference at $P \leq 0.05$. When quantitative factors (e.g., application rate, time) were studied, regressions were calculated instead of ANOVA. The experiments were repeated at least once. All calculations involving bacterial population densities were log-transformed prior to analysis, and means were presented as CFU per unit.

\section{RESULTS}

Suppression of basal kernel blight by $\boldsymbol{P}$. agglomerans in field experiments. In 1994, both the two-row cv. B 1202 and the sixrow cv. B 2601 had less than $4 \%$ of kernels exhibiting symptoms of basal kernel blight, presumably due to hot and dry weather conditions $(0.6 \mathrm{~mm}$ of rainfall) and limited levels of overhead sprinkler irrigation ( 5 days $=150 \mathrm{~mm}$ of precipitation) during the window of infection from heading to soft dough (30). However, the twofactorial variance analysis revealed a significantly lower disease incidence ( $F$ was significant at $P=0.0001$ ) over both cultivars in the treatments in which $P$. agglomerans strains were applied prior to the expected infection window (Table 1). Over all treatments, the disease incidence of cv. B 2601 was $2.1 \%$ and that of cv. B 1202 was $1.6 \%$, although this difference was not significant $(P=$ $0.1186)$. Furthermore, the interaction between the two main factors (cultivar $\times$ treatment) was not significant $(P=0.3835)$. The $P$. agglomerans strains significantly reduced the basal kernel blight percentage by 45 to $68 \%$ on cv. B 2601 when compared with the nontreated controls (Table 1). On cv. B 1202, the blight reduction ranged between 30 to $58 \%$ depending on the bacterial strain used. The Tilt treatment neither increased nor decreased the basal kernel blight disease incidence under field conditions (Table 1). Heat-killed biocontrol strains did not significantly reduce basal blight com-

TABLE 3. Incidence of basal kernel blight disease (\%) on cvs. B 2601 and B 1202 after application of Pantoea agglomerans Eh 239 and Eh 454 in a glasshouse experiment

\begin{tabular}{|c|c|c|c|c|}
\hline \multirow[b]{3}{*}{ Treatment ${ }^{\mathrm{u}}$} & \multicolumn{4}{|c|}{$\%$ Basal kernel blight } \\
\hline & \multicolumn{2}{|c|}{ B 2601} & \multicolumn{2}{|c|}{ B 1202} \\
\hline & Mean $^{v}$ & SD & Mean $^{w}$ & SD \\
\hline Water control & $0^{\mathrm{x}}$ & & $0^{\mathrm{x}}$ & $\ldots$ \\
\hline Pss 552 control & 34.06 & \pm 21.25 & 11.00 & \pm 4.14 \\
\hline Eh $239 \mathrm{D}^{\mathrm{y}}$ & 26.88 & \pm 7.99 & $5.22 * *$ & \pm 3.88 \\
\hline Eh 239 & $12.40 * * \mathrm{z}$ & \pm 4.87 & $0^{\mathrm{x}}$ & \\
\hline Eh 454 & $17.58^{* \mathrm{z}}$ & \pm 5.79 & $1.04 * *$ & \pm 2.33 \\
\hline$P$ & \multicolumn{2}{|c|}{0.0364} & \multicolumn{2}{|c|}{0.0026} \\
\hline
\end{tabular}

u Barley heads were inoculated with Pseudomonas syringae pv. syringae (Pss 552) at the soft dough stage. The water/Tween 20 control, Pantoea agglomerans strains Eh 239 and Eh 454, and the heat-killed strain Eh 239 (D) were applied to barley heads 3 days prior to the Pseudomonas syringae pv. syringae inoculation.

$\checkmark$ Values are means of five replicates $(n=5)$ and data were square root-transformed prior to analysis of variance.

${ }^{\text {w}}$ Values are means of five replicates $(n=5)$.

${ }^{x} 0=$ No disease detected.

${ }^{\mathrm{y}} \mathrm{D}=$ Heat-killed bacteria.

$\mathrm{z} * *=$ Significant disease reduction compared with that of the Pss 552 control at $P \leq 0.05$ using single-degree-of-freedom contrasts. $*=$ Significant disease reduction compared with that of the Pss 552 control at $P \leq 0.1$ using single-degree-of-freedom contrasts. pared with the nontreated water control (Table 1). In 1995, a year with average rainfall $(16 \mathrm{~mm})$ and extended overhead irrigation ( 10 days $=300 \mathrm{~mm}$ of precipitation) during the infection window, significant disease developed with infection percentages in the water controls of 9.5 and $8.9 \%$ for the six-row cvs. B 2601 and B 2912, respectively, and of 7.1 and 5.5\% for the two-row cvs. B 1202 and B 5133, respectively (data not shown). Due to variance in homogeneity, data were log-transformed prior to analysis, and the two-factorial variance analysis revealed significant differences between cultivar means ( $F$ was significant at $P=0.0000)$ and treatment means $(P=0.0000)$. The interaction between cultivar $\times$ treatment was not significant $(P=0.4949)$. Over all treatments, blight percentages were significantly higher in the six-row cvs. B 2601 (6.3\%) and B $2912(6.1 \%)$ compared with those in the two-row cvs. B 1202 (4.1\%) and B 5133 (3.8\%) (data not shown). The disease incidence over all cultivars was lowest (2.6 to 3.5\%) in the $P$. agglomerans-treated plots, with blight reductions ranging from 36 to $74 \%$ when compared with those in the nontreated controls (Table 2 ). Disease reductions by strain combinations also were significant depending on the cultivar. Blight reduction due to strain combinations was 42 to $48 \%$ in cv. B 2601 and 34 to $64 \%$ in cv. B 1202 . However, strain combinations were inferior compared with the application of individual strains (Table 2). In 1995 field experiments, there was a significantly decreased disease incidence over all cultivars in the Tilt-treated plots $(5.7 \%)$. Reductions due to Tilt application ranged between 0 to $43 \%$, which were only significant on cv. B 2601 (Table 2). The tartaric acid treatment resulted in a disease incidence of $6.5 \%$ over all cultivars, which was not significantly different from that in the nontreated water control. However, on cv. B 1202, the blight reduction was $35.7 \%$, which was significant compared with that in the nontreated control. Except for isolate Eh 454D (5.9\%), heat-killed $P$. agglomerans did not significantly reduce the disease incidence over all cultivars (Table 2). Blight reductions were significant only in Eh 454D- and Eh 460Dtreated plots on cv. B 1202 (Table 2).

Performance of $\boldsymbol{P}$. agglomerans in glasshouse tests. Eh 454 and Eh 239 applied to cv. B 12023 days prior to Pseudomonas syringae pv. syringae pathogen inoculation reduced the basal kernel blight infection significantly $(P=0.0026)$ by 91 to $100 \%$ compared with the positive control (Pss 552), which displayed $11 \%$ basal kernel blight disease (Table 3). The heat-killed bacterial suspension Eh 239D, however, also reduced basal kernel blight infection levels significantly by $52 \%$ (Table 3). On cv. B 2601, the infection level due to pathogen application was $34 \%$. Eh 454 significantly reduced the infection by $48 \%$ and Eh 239 by $64 \%(P=$ 0.0364). The heat-killed strain Eh 239D displayed a disease inci-

TABLE 4. Incidence of basal kernel blight disease (\%) on cvs. B 2601 and B 1202 after application of Pantoea agglomerans Eh 236 and Eh 460 in a glasshouse experiment

\begin{tabular}{|c|c|c|c|c|}
\hline \multirow[b]{3}{*}{ Treatment $^{\mathrm{v}}$} & \multicolumn{4}{|c|}{$\%$ Basal kernel blight } \\
\hline & \multicolumn{2}{|c|}{ B 2601} & \multicolumn{2}{|c|}{ B 1202} \\
\hline & Mean ${ }^{w}$ & SD & $\operatorname{Mean}^{\mathrm{x}}$ & SD \\
\hline Water control & $0^{y}$ & & $0^{\mathrm{y}}$ & \\
\hline Pss 552 control & 45.47 & \pm 16.37 & 27.78 & \pm 9.16 \\
\hline Eh 236 & $8.71^{* * *} * \mathrm{z}$ & \pm 7.32 & $0.63^{* * *} *$ & \pm 0.73 \\
\hline Eh 460 & $12.78 * * *$ & \pm 8.76 & $0.07 * * *$ & \pm 0.06 \\
\hline$P$ & \multicolumn{2}{|c|}{0.0005} & \multicolumn{2}{|c|}{0.0000} \\
\hline
\end{tabular}

${ }^{v}$ Barley heads were inoculated with Pseudomonas syringae pv. syringae (Pss 552) at the soft dough stage. The water/Tween 20 control and Pantoea agglomerans strains Eh 236 and Eh 460 were applied to barley heads 3 days prior to the Pseudomonas syringae pv. syringae inoculation.

w Values are means of five replicates $(n=5)$.

${ }^{x}$ Values are means of five replicates $(n=5)$ and data were log-transformed prior to analysis of variance.

y $0=$ No disease detected.

$\mathrm{z} * * *=$ Significant disease reduction compared with that of the Pss 552 control at $P \leq 0.01$ using single-degree-of-freedom contrasts. 
dence of $27 \%$, which was statistically not different from that in the positive control.

Eh 236 and Eh 460 sprayed on cv. B 12023 days prior to Pss 552 inoculation reduced the kernel blight disease significantly by 98 and $100 \%$, respectively, as compared with the inoculated control ( $F$ was significant at $P=0.0000$ ) (Table 4). On cv. B 2601, Eh 236 reduced the blight percentage significantly by $81 \%$, while Eh 460 reduced it by $72 \%(P=0.0005)$ (Table 4$)$.

To investigate the question whether the performance of $P$. agglomerans is consistent over more than one Pseudomonas syringae pv. syringae strain, several BCAs were applied to cv. B 2601 at the soft dough stage prior to inoculation of either Pss 552 or Pss 793. P. agglomerans Eh 460, Eh 234, and Eh 237 significantly

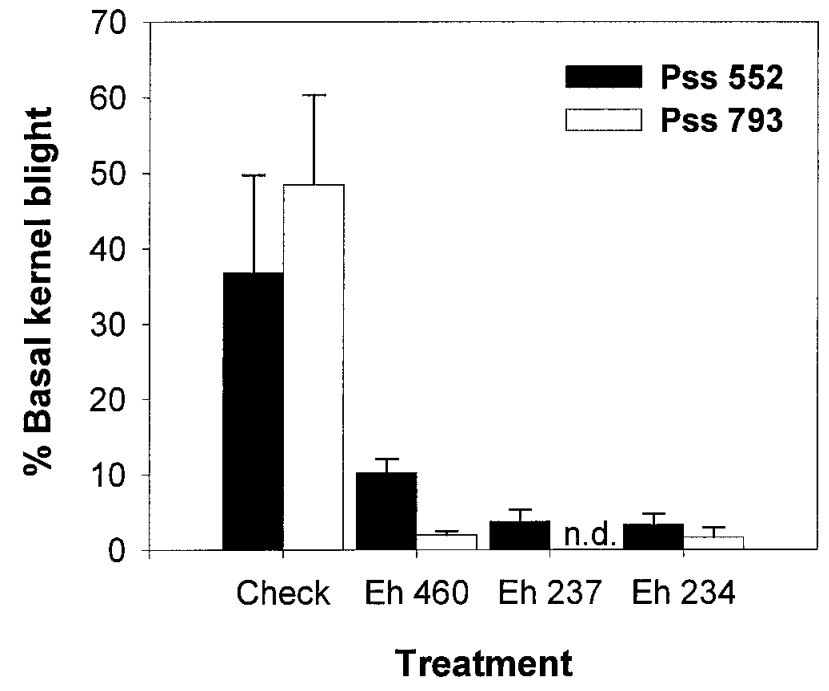

Fig. 1. Effect of application of Pantoea agglomerans strains Eh 460, Eh 237, and Eh 234 on the percentage of basal kernel blight caused by Pseudomonas syringae pv. syringae Pss 552 and Pss 793 on barley cv. B 2601. Antagonistic $P$. agglomerans was applied to spikes in the glasshouse 3 days prior to pathogen inoculation at the soft dough stage. The percentage of basal blight was determined after harvest by counting infected versus noninfected kernels. Error bars represent standard deviations $(n=4)$. n.d. $=$ No disease detected.

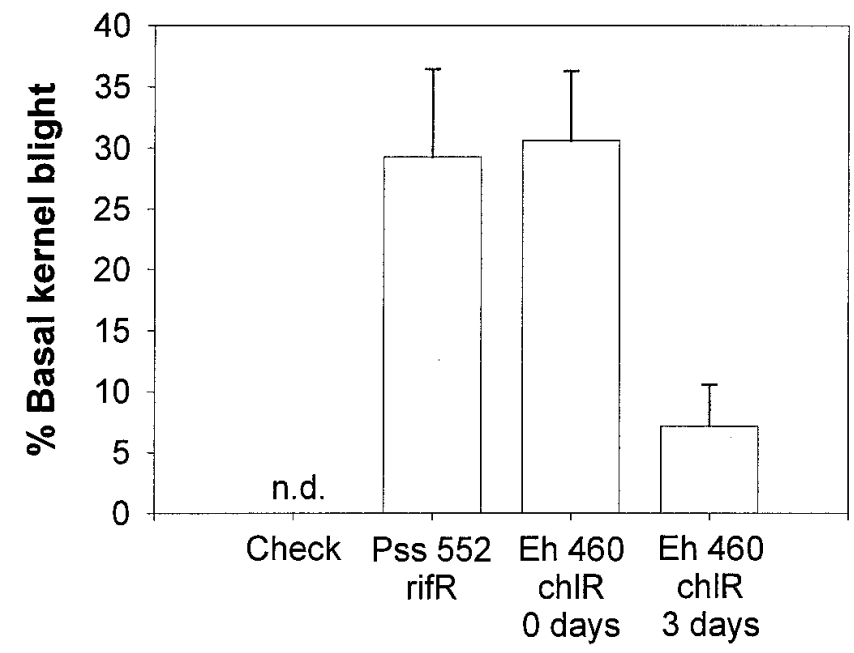

Treatment

Fig. 2. Effect of time of Pantoea agglomerans Eh $460 \mathrm{chl}^{\mathrm{R}}$ application on the percentage of basal kernel blight caused by Pseudomonas syringae pv. syringae Pss 552 rif $^{\mathrm{R}}$ on cv. B 2601. Eh $460 \mathrm{chl}^{\mathrm{R}}$ was applied 3 days prior to (3 days) or coinoculated ( 0 days) with Pss 552 rif $^{\mathrm{R}}$ in a glasshouse experiment at the soft dough stage. The percentage of basal blight was determined after harvest by counting infected versus noninfected kernels. Error bars represent standard deviations $(n=5)$. n.d. $=$ No disease detected. Check is the water/Tween 20 control. reduced basal kernel blight infection levels $(P=0.0000)$ (Fig. 1). Although the kernel infection levels were higher for Pss 793 (48\%) than for Pss 552 (37\%), disease reductions ranged between 96 to $100 \%$ in the Pss 793 system, while they ranged between 72 to $91 \%$ in the Pss 552 system depending on the biocontrol strain tested (Fig. 1).

Time and rate of $\boldsymbol{P}$. agglomerans application. An important factor in the development of an effective biocontrol system is to determine the time and rate of BCA application needed for control. In several glasshouse experiments, we detected that time of application is indeed an aspect to consider when using $P$. agglomerans to protect barley heads from Pseudomonas syringae pv. syringae attack. For instance, when Eh $460 \mathrm{chl}^{\mathrm{R}}$ was applied 3 days prior to Pss 552 rif $^{\mathrm{R}}$ inoculation, inoculation infection levels were reduced significantly by $75 \%$, while no significant disease reduction was noticed when Eh $460 \mathrm{chl}^{\mathrm{R}}$ and Pss $552 \mathrm{rif}^{\mathrm{R}}$ were coinoculated $(P=0.0106)$ (Fig. 2). The treatment of barley heads with Eh

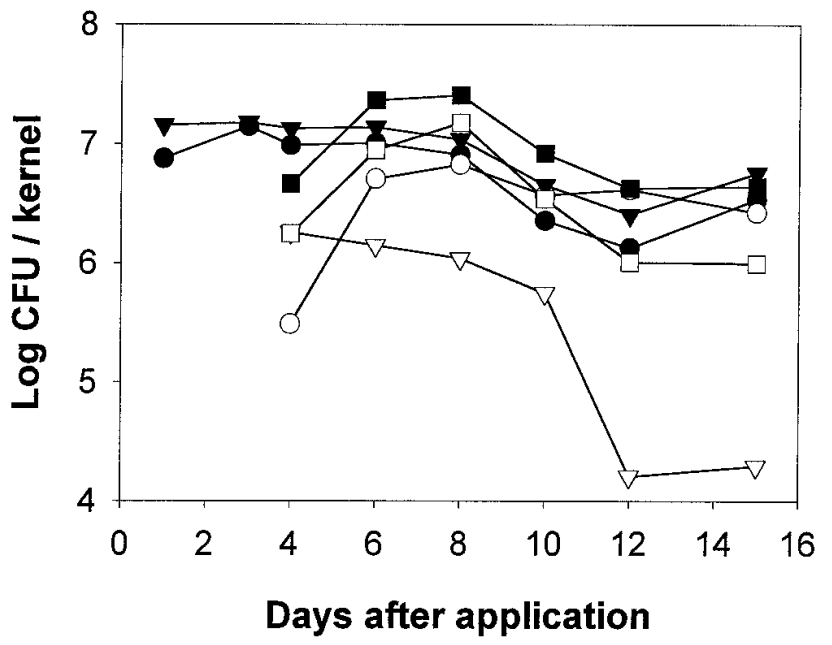

Fig. 3. Population dynamics of Pseudomonas syringae pv. syringae Pss 552 rif $^{\mathrm{R}}$ alone (O), coinoculated with Pantoea agglomerans Eh $460 \mathrm{chl}^{\mathrm{R}}(\square)$, and inoculated 3 days after the introduction of $P$. agglomerans $E h 460 \mathrm{chl}^{\mathrm{R}}(\Delta)$ in the glasshouse at the soft dough stage of kernel development on barley cv. B 2601. The population dynamics of $P$. agglomerans Eh $460 \mathrm{chl}^{\mathrm{R}}$ alone (๑), coinoculated with Pss 552 rif $^{\mathrm{R}}(\boldsymbol{\square})$, and applied 3 days prior to Pss 552 rif $^{\mathrm{R}}$ inoculation ( $\mathbf{A})$ is shown for comparative purposes.

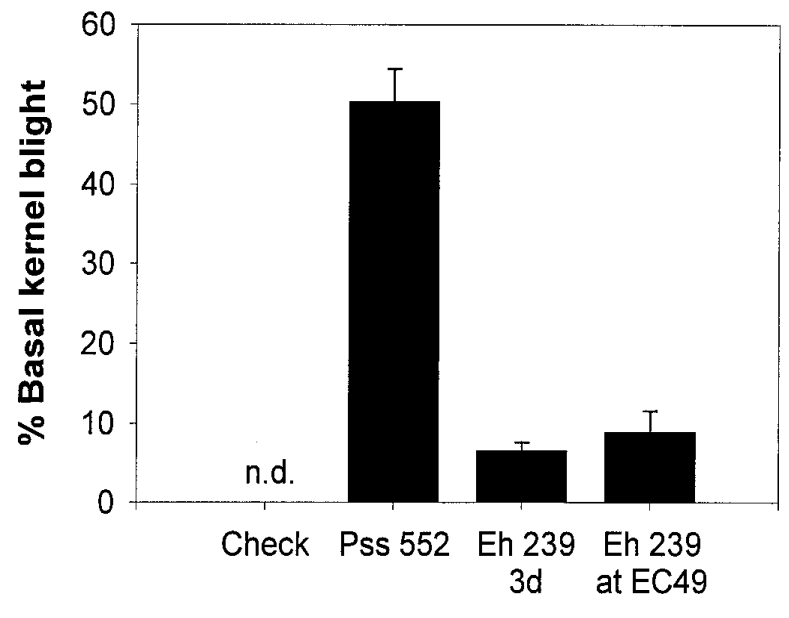

Treatment

Fig. 4. Effect of Pantoea agglomerans strain Eh 239 applied 3 days prior (3d) to pathogen inoculation at the soft dough stage or at the booting stage (EC 49) in the glasshouse on the percentage of basal kernel blight caused by Pseudomonas syringae pv. syringae Pss 552 on barley cv. B 2601. Error bars represent standard deviations $(n=4)$. n.d. $=$ No disease detected. Check is the water/Tween 20 control. 
$460 \mathrm{chl}^{\mathrm{R}}$ alone (data not shown) or the water/Tween control did not result in any basal kernel blight disease symptoms, while the Pss $552 \mathrm{rif}^{\mathrm{R}}$ inoculation revealed $29.3 \%$ infected kernels (Fig. 2), with the pathogen population varying between $3.2 \times 10^{5}$ to $6.3 \times 10^{6} \mathrm{CFU}$ per kernel over a period of 12 days (Fig. 3). The coinoculation of Eh $460 \mathrm{chl}^{\mathrm{R}}$ and Pss 552 rif $^{\mathrm{R}}$ demonstrated no significantly reduced infection levels (30.6\%) (Fig. 2) compared with that in the Pss 552 rif $^{\mathrm{R}}$ control. In this treatment, both the pathogen population and the P. agglomerans population remained between $4.0 \times 10^{6}$ to $2.5 \times 10^{7} \mathrm{CFU}$ per kernel for Eh $460 \mathrm{chl}^{\mathrm{R}}$ and between $1.0 \times 10^{6}$ to $1.6 \times 10^{7}$ for Pss 552 rif $^{\mathrm{R}}$ (Fig. 3). However, the application of Eh $460 \mathrm{chl}^{\mathrm{R}}$ prior to Pss 552 rif $^{\mathrm{R}}$ inoculation resulted in only $7.2 \%$ infected kernels (Fig. 2) and provided statistically significant disease control (75\%). Additionally, the pathogen population decreased 100 -fold over time from $2.0 \times 10^{6}$ to $2.0 \times 10^{4} \mathrm{CFU}$ per kernel (Fig. 3).

For a commercial barley grower, application of BCAs 3 days prior to pathogen attack at the soft dough stage may be too narrow an application window to be practical. Therefore, we investigated whether an earlier BCA application, for instance at the time recommended for the last fungicide application (EC 49), could also lead to a successful biological control of basal kernel blight. Indeed, when Eh 239 was applied to barley heads 3 days prior to Pss 552 inoculation, the infection levels were significantly decreased by $87 \%$ ( $F$ was significant at $P=0.0000$ ) (Fig. 4 ). When it was applied at EC 49 , it decreased infection significantly by $82 \%$, which was not different from that of the application 3 days prior to Pss 552 inoculation. Thus, the window for effective application of the BCA is at least between EC 49 and EC 85 .

The concentration of the antagonist Eh 460 needed to successfully suppress the occurrence of basal kernel blight was tested at

TABLE 5. Effect of increasing dosages $\left(10^{3}, 10^{5}\right.$, and $\left.10^{7} \mathrm{CFU} / \mathrm{ml}\right)$ of Pantoea agglomerans Eh 460 application in the glasshouse on the percentage of basal kernel blight caused by Pseudomonas syringae pv. syringae Pss 552 on cv. B 2601 and on the percentage of disease reduction

\begin{tabular}{|c|c|c|c|c|c|}
\hline \multirow[b]{2}{*}{ Treatment $^{\mathrm{w}}$} & \multirow{2}{*}{$\begin{array}{c}\text { Dose } \\
(\mathrm{CFU} / \mathrm{ml})\end{array}$} & \multicolumn{3}{|c|}{$\%$ Basal kernel blight } & \multirow{2}{*}{$\begin{array}{l}\% \text { Disease } \\
\text { reduction }\end{array}$} \\
\hline & & $\operatorname{Mean}^{\mathrm{x}}$ & SD & $P$ value & \\
\hline Water control & 0 & $0^{\mathrm{y}}$ & & $\ldots$ & $\ldots$ \\
\hline Pss 552 control & 0 & 26.3 & \pm 10.84 & & $\ldots$ \\
\hline Eh 460 & $10^{3}$ & $7.1^{* * * * \mathrm{z}}$ & \pm 5.66 & 0.006 & 73.0 \\
\hline Eh 460 & $10^{5}$ & $7.5^{* * * *}$ & \pm 8.21 & 0.002 & 71.5 \\
\hline Eh 460 & $10^{7}$ & $3.0 * * *$ & \pm 1.81 & 0.000 & 89.0 \\
\hline
\end{tabular}

${ }^{\mathrm{w}}$ Eh 460 was applied to barley spikes 3 days prior to pathogen inoculation at the soft dough stage.

${ }^{x}$ Values are means of six replicates per treatment and data were log-transformed prior to analysis.

y $0=$ No disease detected.

$\mathrm{z} * * *=$ Significant disease reduction compared with the Pss 552 control at $P \leq$ 0.01 using orthogonal contrasts. rates of $10^{3}, 10^{5}$, and $10^{7} \mathrm{CFU} / \mathrm{ml}$. When barley heads were inoculated with the pathogen Pss 552 without prior protection by $P$. agglomerans, $26 \%$ of the kernels were infected. Since concentration is a quantitative factor, means were separated by orthogonal contrasts comparing every Eh 460 dose rate with the nontreated positive control. When Eh 460 was applied 3 days prior to the pathogen inoculation at a low rate of $10^{3} \mathrm{CFU} / \mathrm{ml}$, the percentage of infected kernels was significantly reduced to $7.1 \%(P=0.006)$ (Table 5). Application of Eh 460 at a rate of $10^{5} \mathrm{CFU} / \mathrm{ml}$ also demonstrated significantly reduced blight levels $(7.5 \%)(P=0.002)$. However, the best disease control was reached when Eh 460 was applied at a concentration of $10^{7} \mathrm{CFU} / \mathrm{ml}$. Only $3 \%(P=0.000)$ infected kernels were recorded, which is under the critical threshold level of $4 \%$ in a 100 -g sample.

Formulation of $\boldsymbol{P}$. agglomerans. The development of BCAs into commercial products is dependent on stable, efficacious, and economical formulations (42). Over all formulations tested, the oil/starch/sugar (USDA) formulation stored at $4^{\circ} \mathrm{C}$ was better for bacterial survival than was storage at $22^{\circ} \mathrm{C}$, although this difference was not significant when calculated over time (Table 6). However, after 547 days (1.5 years) of storage at $4{ }^{\circ} \mathrm{C}, 94 \%$ of $\mathrm{Eh} 239$ bacteria and $95 \%$ of EhL13 bacteria survived in the USDA formulation. Survival rates dropped to $77 \%$ for Eh 239 and $74 \%$ for EhL13 when stored at $22^{\circ} \mathrm{C}$. Despite storage at $4^{\circ} \mathrm{C}$, lyophilization (FD) was significantly less efficient for bacterial survival than was the USDA formulation and resulted in only $75 \%$ survival of Eh 239. Dry milk formulation (DM) of EhL13 stored at $22^{\circ} \mathrm{C}$ was better in its survival rate $(82 \%)$ than was the USDA formulation stored at $22^{\circ} \mathrm{C}(74 \%)$, although this difference was not significant. Comparing bacterial survival in the formulations from day 1 to the end of the storage period (day 1 versus day 547), we noted no significant differences in bacterial survival only with Eh 239 in the USDA formulation stored at $4^{\circ} \mathrm{C}(P=0.3654)$. Second best was EhL13 in the USDA formulation stored at $4^{\circ} \mathrm{C}$. Here, the reduction in bacterial survival was only significant when tested at the $10 \% \alpha$ level. In all other cases, the difference in bacterial survival at the beginning and end of the storage period was moderately $(P \leq$ $0.05)$ to highly $(P \leq 0.01)$ reduced. Over all treatments, the regression coefficient over time was $r=-0.7005(P<0.001$, with the regression curve of $y=-0.297 x+10.3)$.

\section{DISCUSSION}

Field experiments in 1994 and 1995 demonstrated 45 to $74 \%$ reductions in basal kernel blight-infected seeds of plants sprayed with $P$. agglomerans prior to the Pseudomonas syringae pv. syringae infection window. Glasshouse experiments resulted in 50 to $100 \%$ disease reduction depending on the barley cultivar used and biocontrol strain screened. A difference in susceptibility of culti-

TABLE 6. Long-term survival of Pantoea agglomerans strains Eh 239, EhL13, and Eh 460 after 1, 14, 28, 91, 182, 365, and 547 days of storage in the oil/starch/sugar formulation (USDA), and lyophilized in dry milk powder (FD) and in the oil/starch/dry milk formulation (DM) at 4 or $22^{\circ} \mathrm{C}$, respectively

\begin{tabular}{|c|c|c|c|c|c|c|c|c|c|c|c|c|}
\hline \multirow[b]{2}{*}{ Formulation } & \multirow{2}{*}{$\begin{array}{c}\text { Strain/storage } \\
\text { temperature }\end{array}$} & \multicolumn{7}{|c|}{ Days past formulation } & \multirow{2}{*}{$\begin{array}{c}\text { Average } \\
\text { formulation }^{\mathrm{u}}\end{array}$} & \multirow{2}{*}{$\begin{array}{l}\mathrm{LSD}_{(0.05)} \\
\text { time }\end{array}$} & \multirow{2}{*}{$\begin{array}{c}\% \\
\text { Survivalv }^{\mathrm{v}}\end{array}$} & \multirow{2}{*}{$\begin{array}{c}P \text { value }{ }^{\mathrm{w}} \\
t \text { test }\end{array}$} \\
\hline & & 1 & 14 & 28 & 91 & 182 & 365 & 547 & & & & \\
\hline USDA & Eh $239 / 22^{\circ} \mathrm{C}$ & $10.0^{\mathrm{x}}$ & 9.8 & 9.3 & 9.0 & 8.8 & 7.7 & 7.7 & $8.89 \mathrm{BC}$ & $\ldots$ & 77 & $0.0388 * * \mathrm{y}$ \\
\hline USDA & Eh $239 / 4^{\circ} \mathrm{C}$ & 10.0 & 9.3 & 9.7 & 9.5 & 10.0 & 8.6 & 9.4 & $9.50 \mathrm{AB}$ & $\ldots$ & 94 & $0.3654 \mathrm{~ns}$ \\
\hline USDA & EhL $13 / 22^{\circ} \mathrm{C}$ & 10.3 & 9.9 & 9.7 & 9.0 & 8.9 & 7.8 & 7.6 & $9.03 \mathrm{AB}$ & $\ldots$ & 74 & $0.0005^{* * *} *$ \\
\hline USDA & $\mathrm{EhL} 13 / 4^{\circ} \mathrm{C}$ & 10.3 & 9.8 & 9.6 & 9.3 & 9.5 & 8.7 & 9.8 & $9.56 \mathrm{~A}$ & $\ldots$ & 95 & $0.0723 *$ \\
\hline FD & $\mathrm{Eh} 239 / 4^{\circ} \mathrm{C}$ & 9.9 & 8.5 & 8.3 & 8.4 & 8.5 & 7.6 & 7.4 & $8.37 \mathrm{C}$ & $\ldots$ & 75 & $0.0008 * * *$ \\
\hline $\mathrm{DM}$ & $\mathrm{EhL} 13 / 22^{\circ} \mathrm{C}$ & 10.3 & 10.0 & 9.6 & 9.5 & 9.0 & 8.5 & 8.4 & $9.33 \mathrm{AB}$ & $\ldots$ & 82 & $0.0136 * *$ \\
\hline $\operatorname{LSD}_{(0.05)}$ formulation & $\ldots$ & $\ldots$ & $\ldots$ & $\ldots$ & $\ldots$ & $\ldots$ & $\ldots$ & $\ldots$ & 0.6203 & $\ldots$ & $\ldots$ & $\ldots$ \\
\hline Average time ${ }^{z}$ & $\ldots$ & $10.13 \mathrm{~A}$ & $9.56 \mathrm{AB}$ & $9.35 \mathrm{~B}$ & $9.10 \mathrm{~B}$ & $9.13 \mathrm{~B}$ & $8.15 \mathrm{C}$ & $8.37 \mathrm{C}$ & $\ldots$ & 0.6203 & $\ldots$ & $\ldots$ \\
\hline
\end{tabular}

u Values $(\log \mathrm{CFU} / \mathrm{g})$ are mean of formulation treatments over time.

v Values represent the percentage of surviving bacteria comparing formulation treatments 1 day versus 547 days.

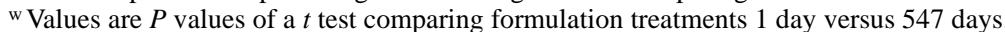

${ }^{x}$ Values ( $\log \mathrm{CFU} / \mathrm{g}$ of formulation) are mean of three plate replicates $(n=3)$.

y Significant differences between treatment means at $P \leq 0.1(*), P \leq 0.05(* *)$, and $P \leq 0.01(* *)$; ns $=$ not significant; and $\ldots=$ not applicable.

${ }^{\mathrm{z}}$ Values $(\log \mathrm{CFU} / \mathrm{g})$ are mean of time over all formulation treatments. 
vars to Pseudomonas syringae pv. syringae has been demonstrated in previous experiments (30). These results were confirmed here. A tendency was found that the efficacy of $P$. agglomerans to decrease the infection percentages depends on the susceptibility of the cultivars to the pathogen. Since the susceptibility of six-row cultivars in general is higher, the efficacy of $P$. agglomerans is greater on the six-row cultivars such as B 2601 and B 2912 than on the two-row cvs. B 1202 and B 5133. However, no significant interactions were observed in field experiments in 1994 and 1995. Reduction due to a Tilt application in the 1995 field trials could either be related to decreasing kernel blight-inducing fungi or an effect of Tilt on Pseudomonas syringae pv. syringae. An effect of Tilt on Pseudomonas syringae pv. syringae was revealed in a batch culture bioassay, when Tilt levels were above $100 \mu \mathrm{g} / \mathrm{ml}$, which is usually exceeded in field applications (A. Braun-Kiewnick and B. J. Jacobsen, unpublished data). Similar good levels of disease control by $P$. agglomerans in field trials have been demonstrated in other systems. Lindow et al. (27) obtained 50\% less frost damage on field-grown corn plants treated with INA-minus $P$. agglomerans (lacking ice nucleation activity). Under controlled environmental conditions, they achieved 88 to $100 \%$ frost damage (26). Protection from fire blight ( 42 to $51 \%$ ) was demonstrated in research orchards by spraying apple blossoms with $P$. agglomerans 1 day prior to E. amylovora inoculation (6). Isenbeck and Schulz (19) saw 20 to $40 \%$ fire blight disease reduction using $P$. agglomerans under field conditions following natural infection with $E$. amylovora. More recently, Wilson et al. (40) observed the reduction of fire blight of hawthorn with $P$. agglomerans isolates under controlled environmental conditions. One isolate provided over $80 \%$ control of blossom blight and $100 \%$ control of shoot blight when applied at a BCA-to-pathogen ratio of 10:1. Field trials conducted with $P$. agglomerans isolates in Oregon in 1991 and 1992 and in Washington in 1992 revealed a 88\% fire blight disease reduction in pear blossoms in Oregon in 1991 compared that in with the water controls. In 1992, the disease was reduced by $50 \%$ in Oregon and by $56 \%$ in Washington (20).

Glasshouse and field recovery data demonstrated that rifampicinresistant $P$. agglomerans strains were established at stable levels in the barley phyllosphere after their initial introduction $(10,12)$. They could be recovered in high numbers $\left(3.0 \times 10^{6}\right.$ to $3.0 \times 10^{7} \mathrm{CFU}$ per kernel) over a period of time known to be critical for Pseudomonas syringae pv. syringae attack, suggesting one-time foliar spray application may be sufficient for controlling basal kernel blight. Many bacterial antagonists effectively colonize emerging and mature plant tissues for relatively long periods of time (1 to 3 months) following a single foliar application (25). However, time of BCA application was critical with respect to disease control. In the glasshouse, the rifampicin-resistant pathogen population was reduced 100 -fold after the introduction of the chloramphenicol-resistant Eh $460 \mathrm{chl}^{\mathrm{R}}$ population 3 days prior to the Pss $552 \mathrm{rif}^{\mathrm{R}}$ inoculation, while no reduction was observed when Eh $460 \mathrm{chl}^{\mathrm{R}}$ and Pss 552 rif $^{\mathrm{R}}$ were coinoculated. Disease control data correlated well with population dynamics. Kernel blight infection was significantly reduced when plants were treated with the BCA Eh $460 \mathrm{chl}^{\mathrm{R}}$ before inoculation with the pathogen, while no disease control was observed when $P$. agglomerans and the pathogen were coinoculated. $P$. agglomerans could even be applied as early as before heading (EC 49), the stage relevant for the last fungicide application against foliar pathogens. This offers the possibility of combining fungicide applications with BCAs in commercial barley fields in an integrated disease control program. Similar population dynamics with respect to frost damage prevention have been found by Lindow et al. (27). An INA-minus $P$. agglomerans isolate decreased the population of epiphytic INA-plus bacteria 10- to 100-fold in growth chamber and field experiments. More recently, Johnson et al. (20) reported a direct relationship between a lower E. amylovora population on pear blossoms treated with bacterial antagonists and fire blight reduction. Lindow et al. (26) also demon- strated that the percentage of leaves damaged by frost decreased significantly when the INA-minus antagonists were applied any time before, and up to $12 \mathrm{~h}$ after, application of the INA-plus pathogen. This was different from our studies, in which the antagonists had to be present prior to the pathogen and a coinoculation of antagonist and pathogen did not lead to successful disease prevention. Increasing rates of Eh $460\left(10^{3}\right.$ to $\left.10^{7} \mathrm{CFU} / \mathrm{ml}\right)$ applied 3 days prior to pathogen inoculation resulted in better disease control. This indicated a desirable rate of $P$. agglomerans application at $10^{7} \mathrm{CFU} / \mathrm{ml}$ for disease control below a critical $4 \%$ threshold. However, it should be noted that concentrations as low as $10^{3}$ to $10^{5} \mathrm{CFU} / \mathrm{ml}$ still reduced the disease significantly. Similarly, frost damage on corn decreased with increasing densities of an INA-minus $P$. agglomerans isolate applied $24 \mathrm{~h}$ before inoculation with an INA-plus isolate (26). Best control was achieved by spray application of $10^{8} \mathrm{CFU} / \mathrm{ml} 24 \mathrm{~h}$ prior to inoculation of INA-plus bacteria (26). In addition, the reduced potential of $P$. agglomerans to protect individual bean blossoms from infection by Sclerotinia sclerotiorum suggested that low temperatures within the canopy may have limited the ability of $P$. agglomerans to multiply to levels needed for disease control (41).

A central issue in developing BCAs into commercial products is the large-scale, cost-efficient production and delivery of bacterial antagonists to the plant. Advances here are likely to be the single most important contribution to biological control in the coming decade (4). Dry preparations seem to be best for commercial formulations of bacteria. Therefore, screening potential antagonists for survival and activity as early as possible seems warranted (24). Since there has been little progress with formulations in phylloplane microbiology, we addressed the question of long-term viability of $P$. agglomerans in storage (at least 6 months, preferably 1 to 2 years). The USDA wettable powder formulation $(33,42)$ preserved the viability of the tested Gram-negative $P$. agglomerans strains efficiently over a period of 1.5 years. While differences between treatments were not significant in most cases because of variability over time, survival of formulated bacteria stored at $4^{\circ} \mathrm{C}$ was generally better than that with storage at $22^{\circ} \mathrm{C}$. An effect of temperature on survival of Pseudomonas syringae pv. tabaci in a sucrose/oil granular formulation has been reported by Quimby et al. (33). Bacterial survival was $63 \%$ when stored at $22^{\circ} \mathrm{C}$ for 365 days compared with $94 \%$ when stored at $2{ }^{\circ} \mathrm{C}$. Replacement of starch by dry skim milk in the oil/starch/sugar encapsulation method (USDA) of EhL13 stored at $22^{\circ} \mathrm{C}$ did not reveal any differences between the two formulations as to viability, suggesting that dry milk encapsulates the active bacterial cells as efficiently as starch, and promotes bacterial biofilm formation and adherence of the encapsulated bacteria to treated foliage (33). While differences in disease reduction between Eh 239 formulations applied prior to pathogen attack and the unprotected Pss 552 control were significant, we detected no statistical differences between the different Eh 239 formulations and the storage at different temperatures in a glasshouse test (10). Thus, the biocontrol efficacy of formulated $P$. agglomerans Eh 239 after 1.5 years of storage was not negatively influenced by formulation or by storage temperature.

In conclusion, $P$. agglomerans isolates indigenous to healthy barley kernels were selected for their ability to reduce kernel blight induced by Pseudomonas syringae pv. syringae. Our data indicated that the above-described organisms, when applied prior to the infection window, reduced the epiphytic population size of Pseudomonas syringae pv. syringae $(10,12)$ and, consequently, basal kernel blight infection of barley $(10,13)$. Thus, given the unavailability of synthetic bactericides and the known restrictions and regulations of using antibiotics in field applications, $P$. agglomerans bacteria may represent promising BCAs. They could be used in addition to less-susceptible cultivars and reduced irrigation during the infection window to prevent the occurrence of this disease. The mechanisms by which the antagonists interact with the pathogen to control basal kernel blight have been investigated $(10,11,14)$ but will be discussed elsewhere. 


\section{ACKNOWLEDGMENTS}

This study was partially supported by a grant from Anheuser Busch Inc. and by the Department of Plant Pathology of Montana State University. We thank J. Jerome, T. Thomas, C. Morgan, and A. Rose for technical assistance with the field and lab work, and S. Kiewnick for critically reviewing this manuscript.

\section{LITERATURE CITED}

1. Adetuyi, F. C. 1992. Antagonistic potential of Pseudomonas syringae and Erwinia herbicola on wheat seeds. Indian J. Mycol. Plant Pathol. 22(3): 250-254.

2. Amellal, N., Burtin, G., Bartolli, F., and Heulin, T. 1998. Colonization of wheat roots by an exopolysaccharide-producing Pantoea agglomerans strain and its effect on rhizosphere soil aggregation. Appl. Environ. Microbiol. 64:3740-3747.

3. Anderson, W. H., and Banttari, E. E. 1976. The effect of Bipolaris sorokiniana on yield, kernel weight and kernel discoloration in six-row spring barleys. Plant Dis. Rep. 60:754-758.

4. Andrews, J. H. 1992. Biological control in the phyllosphere. Annu. Rev. Phytopathol. 30:603-635.

5. Basson, A. B. K., de Villiers, O. T., and Rabie, C. J. 1990. Effect of black ends on quality characteristics of clipper barley and malt. J. Am. Soc. Brew. Chem. 48(1):8-13.

6. Beer, S. V., Rundle, J. R., and Norelli, J. L. 1984. Recent progress in the development of biological control of fire blight-A review. Acta Hortic. 151:195-201.

7. Beer, S. V., Rundle, J. R., and Wodzinski, R. S. 1984. Interaction between Erwinia amylovora and Erwinia herbicola in vitro, in immature pear fruits and in apple blossoms. Acta Hortic. 151:203-204.

8. Berg, G., and Ballin, G. 1994. Bacterial antagonists to Verticillium dahliae Kleb. J. Phytopathol. (Berl.) 141:99-110.

9. Bora, L. C., Gangopadhyay, S., and Chaud, J. N. 1993. Biological control of bacterial leaf spot (X. campestris pv. vignaeradiatae Dye) of mung bean with phylloplane antagonists. Indian J. Mycol. Plant Pathol. 23:162-168.

10. Braun, A. 1998. Studies on the basal kernel blight disease of barley: Pathogenesis and phylogeny of the causal agent Pseudomonas syringae pv. syringae and its biological control by antagonistic Pantoea agglomerans. Ph.D. thesis. Montana State University, Bozeman.

11. Braun, A., Jacobsen, B. J., and Sands, D. C. 1997. Possible biocontrol mechanisms in the Pseudomonas syringae-Pantoea agglomerans interaction. (Abstr.) Phytopathology 87(suppl.):S11.

12. Braun, A., Rose, A., Kaliyeva, G. T., Martinez-Miller, C., and Sands, D. C. 1996. Biocontrol of bacterial kernel blight of barley by beneficial Pantoea agglomerans. (Abstr.) Phytopathology 86(suppl.):S79.

13. Braun, A., Sands, D. C., and Jacobsen, B. J. 1997. Suppression of bacterial kernel blight of barley by antagonistic Pantoea agglomerans. Biol. Cult. Tests Control Plant Dis. 12:105.

14. Braun, A., Sands, D. C., and Jacobsen, B. J. 1998. Mechanisms in the biological control of Pseudomonas syringae pv. syringae by Pantoea agglomerans. In: Molecular Approaches in Biological Control. B. K. Duffy, U. Rosenberger, and G. Defago, eds. IOBC Bull. 21(9):7-12.

15. Gavini, F., Mergaert, J., Beji, A., Mielcarek, C., Izard, D., Kersters, K., and de Ley, J. 1989. Transfer of Enterobacter agglomerans (Beijerinck 1888) Ewing and Fife 1972 to Pantoea gen. nov. as Pantoea agglomerans comb. nov. and description of Pantoea dispersa sp. nov. Int. J. Syst. Bacteriol. 39:337-345.

16. Hildebrand, D. C., Schroth, M. N., and Sands, D. C. 1988. Pseudomonas. Pages 60-80 in: Laboratory Guide for Identification of Plant Pathogenic Bacteria, 2nd ed. N. W. Schaad, ed. The American Phytopathological Society, St. Paul, MN.

17. Holt, J. G., Krieg, N. R., Sneath, P. H. A., Staley, J. T., and Williams, S. T., eds. 1994. Group 5. Page 184 in: Bergey's Manual of Determinative Bacteriology. 9th ed. Williams \& Wilkins, Baltimore, MD.

18. Hsieh, S. P. Y., and Buddenhagen, I. W. 1974. Suppressing effects of Erwinia herbicola on infection by Xanthomonas oryzae and on symptom development in rice. Phytopathology 64:1182-1185.

19. Isenbeck, M., and Schulz, F. A. 1985. Biological control of fire blight (Erwinia amylovora [Burr.] Winslow et al.) on ornamentals. I. Control of the pathogen by antagonistic bacteria. Phytopathol. Z. 113:324-333.

20. Johnson, K. B., Stockwell, V. O., McLaughlin, R. J., Sugar, D., Loper, J. E., and Roberts, R. G. 1993. Effects of antagonistic bacteria on establishment of honey bee-dispersed Erwinia amylovora in pear blossoms and on fire blight control. Phytopathology 83:995-1002.

21. Kearns, L. P., and Hale, C. N. 1995. Incidence of bacteria inhibitory to Erwinia amylovora from blossoms in New Zealand apple orchards. Plant Pathol. 44:918-924.

22. Kempf, H.-J., and Wolf, G. 1989. Erwinia herbicola as a biocontrol agent of Fusarium culmorum and Puccinia recondita f. sp. tritici on wheat. Phytopathology 79:990-994.

23. King, E. O., Ward, M. K., and Raney, D. E. 1954. Two simple media for the demonstration of pyocyanin and fluorescein. J. Lab. Clin. Med. 44: 301-307.

24. Leben, C. 1985. Introductory remarks: Biological control strategies in the phylloplane. Pages 1-5 in: Biological Control on the Phylloplane. C. E. Windels and S. E. Lindow, eds. The American Phytopathological Society, St. Paul, MN.

25. Lindow, S. E. 1985. Integrated control and role of antibiosis in biological control of fire blight and frost injury. Pages 83-115 in: Biological Control on the Phylloplane. C. E. Windels and S. E. Lindow, eds. The American Phytopathological Society, St. Paul, MN.

26. Lindow, S. E., Arny, D. C., and Upper, C. D. 1983. Biological control of frost injury: An isolate of Erwinia herbicola antagonistic to ice nucleation active bacteria. Phytopathology 73:1097-1102.

27. Lindow, S. E., Arny, D. C., and Upper, C. D. 1983. Biological control of frost injury: Establishment and effects of an isolate of Erwinia herbicola antagonistic to ice nucleation active bacteria on corn in the field. Phytopathology 73:1102-1106.

28. Martinez-Miller, C. 1994. Etiology and characterization of two Pseudomonas syringae pathovars causing two bacterial kernel blights of barley. Ph.D. thesis. Montana State University, Bozeman.

29. Martinez-Miller, C., and Braun, A. 1997. Bacterial kernel blights. Pages 5-7 in: Compendium of Barley Diseases. 2nd ed. D. E. Mathre, ed. The American Phytopathological Society, St. Paul, MN.

30. Martinez-Miller, C., Braun, A., Siemsen, S., and Sands, D. C. 1997. Etiology of basal kernel blight of barley caused by Pseudomonas syringae pv. syringae. Can. J. Plant Pathol. 19(4):337-346.

31. Mohan, S. K., and Schaad, N. W. 1987. An improved agar plating assay for detecting Pseudomonas syringae pv. syringae and P. s. pv. phaseolicola in contaminated bean seed. Phytopathology 77:1390-1395.

32. Nelson, E. B. 1988. Biological control of Pythium seed rot and preemergence damping-off of cotton with Enterobacter cloacae and Erwinia herbicola applied as seed treatments. Plant Dis. 72:140-142.

33. Quimby, P. C., Caesar, A. J., Birdsall, J. L., Connick, W. J., Boyette, C. D., Zidack, N. K., and Grey, W. E. 1996. Granulated formulation and method for stabilizing biocontrol agents. U.S. patent 08/695249.

34. Randhawa, P. S., Singh, N. J., and Schaad, N. W. 1987. Bacterial flora of cotton seeds and biocontrol of seedling blight caused by Xanthomonas campestris pathovar malvacearum. Seed Sci. Technol. 15:65-72.

35. Rosales, A. M., Vantomme, R., Swings, J., de Ley, J., and Mew, T. W. 1993. Identification of some bacteria from paddy antagonistic to several rice fungal pathogens. J. Phytopathol. (Berl.) 138(3):189-208.

36. Ruppel, S., Wache, H., and Höflich, G. 1989. Wirkprinzipien zur Wachstumsstimulierung von Winterweizen durch $\mathrm{N}_{2}$-fixierende assoziative Rhizosphärenmikroorganismen. Forschungsber. FZB Müncheberg FO 999.

37. Scholz-Seidel, C., and Ruppel, S. 1992. Nitrogenase- and phytohormone activities of Pantoea agglomerans in culture and their reflection in combination with wheat plants. Zentralbl. Microbiol. 147:319-328.

38. Stockwell, V. O., Johnson, K. B., and Loper, J. E. 1994. Influence of inoculum preparation on establishment of bacterial antagonists on pear and apple blossoms. (Abstr.) Phytopathology 84:1114.

39. Sujkowski, L. S., Ophir, Y., Fry, W. E., and Beer, S. V. 1994. Antibioticproducing strain of Erwinia herbicola as a potential biological control agent for Alternaria solani. (Abstr.) Phytopathology 84:1082.

40. Wilson, M., Epton, H. A. S., and Sigee, D. C. 1990. Biological control of fire blight of hawthorn (Crataegus monogyna) with Erwinia herbicola under protected conditions. Plant Pathol. (Oxf.) 39:301-308.

41. Yuen, G. Y., Craig, M. L., Kerr, E. D., and Steadman, J. R. 1994. Influences of antagonist population levels, blossom development stage, and canopy temperature on the inhibition of Sclerotinia sclerotiorum on dry edible bean by Erwinia herbicola. Phytopathology 84:495-501.

42. Zidack, N. K., Quimby, Jr., P. C., and Caesar, A. J. 1995. An oil/starch/ sugar encapsulation method suitable for Gram-negative bacteria and other microbes. (Abstr.) Phytopathology 85:1213. 